By R. D. JAMESON

\title{
Consultant Service and the College Library
}

Mr. Jameson, Administrator of Consultant Service, Library of Congress, presented this paper at a meeting of the College Libraries Section of the Association of College and Reference Libraries, December 29, 1941 .

$\mathrm{T}$ he Consultant Service of the Library of Congress looks toward the solution of two of the major problems and a very large number of minor but important problems confronting the research libraries of this era. The first of the general problems might be referred to as the bibliophobia of scholars. The second, the wild book, has been discussed by Ortega y Gasset in his significant article, "Man Must Tame the Book."

The bibliophobia of scholars is a problem well recognized by all of us who have to do with research libraries. It may be the fault of the older school of librarians who liked to keep their books on the shelves, but I think the cause lies deeper. It seems to be a law of nature, like one of the laws of thermodynamics, that there is a repulsion between librarians who keep books and research men who use books; it seems to be a war which is without truce and without prospect of peace. We all know that librarians want to know where their books are in order to keep the record, and that the record (in theory at least, though now and again librarians $\sin$ ) is not kept for the sake of the record but kept simply to make more books available to more people more frequently. There are few scholars who will not concur with this reasonable view when it is explained to them. There are many, however, who, having concurred, continue placidly to take the books off the shelves and into their offices without making a record. There is goodwill on both sides but unfortunately a difficulty in implementing the goodwill. Consultant Service, which brings research men into the library for a year or longer as members of the staff, gives them an opportunity to survey their field in its entirety, and an opportunity to talk to librarians as colleagues rather than as enemies, may, in the course of time, bring to research workers an understanding of what our problems are and why they are problems.

The wildness of books is the second large problem this generation is facing. It is not necessary for me to remind you of the enormous speed with which printed matter is being produced or of the difficulties experienced in deciding with budgets always too small which of the materials are likely to be of the greatest use. Ortega $y$ Gasset has warned us that if we do not tame the book our culture will revolt against it. The books will overwhelm us. There is, in fact, evidence that the present generation of undergraduates is already 
turning against books, that the present generation is becoming increasingly illiterate; that even where the college libraries are good libraries, with collections thoughtfully selected and attractively displayed, undergraduates, and in some colleges even faculties, continue to avoid the library. To put research people in libraries as part of the library staff (providing always they are men or women with scholarly vision), to request them to guide the undergraduates in their reading is one way of taming the books.

Librarians of Congress and other librarians long before the Library of Congress was established, have dreamed of associating with themselves subject specialists who will assist them in their many tasks. In 1806 Senator Mitchill, in a report from the Senate Library Committee, said the aim of purchasing books was

to furnish the library with such materials as will enable statesmen to be correct in their investigations, and by a becoming display of erudition and research, give a higher dignity and a brighter luster to truth.

In 1897 Melvil Dewey, in hearings before the Joint Committee on the Library, observed that

... specialists would be simply invaluable. You could begin with a few who would divide the field among them; one in history, another in science, another in art, another in social science, in law, in literature, in philosophy ; but I predict that the public usefulness of such officers will be so great that within a few years their number will be largely increased and that the National $\mathrm{Li}$ brary will become in fact a bibliographic university.

\section{Realization of Ideal}

Progress in the realization of this ideal has been slow. According to law, until I 925 any money received by the Library of
Congress was paid into the Treasury of the United States and had to be reappropriated by Congress for any special undertaking. Consequently, the librarian was unable to engage in experiments which, though they had every promise of being successful, could not be demonstrated to fulfill a need of the library. Moreover, private individuals and foundations were loath to deposit funds in the Treasury of the United States inasmuch as the librarian could, on his own word, give no formal assurance that the funds would be used for the purpose desired. In March of 1925 a joint resolution was passed establishing a trust fund. The officers of the fund are ex officio, the Secretary of the Treasury, the Librarian of Congress, the Chairman of the Joint Committee on the Library, and two citizens. The trust fund is a quasi-corporation. Its funds are deposited in the Treasury of the United States and the Treasurer of the United States has undertaken to pay on them 4 per cent interest in perpetuity.

Although from time to time Librarians of Congress have succeeded in associating with themselves research men of great brilliance, the Consultant Service as such was not formally constituted until about a decade ago. At that time Dr. Putnam was enabled to invite to become consultants of the library a number of subject specialists, most of them professors emeritus, who would spend half their time in the library at a nominal honorarium and advise the librarian on his collections. These scholars worked faithfully within the terms of this agreement. Shortly after Mr. MacLeish assumed office, however, it became clear to him that more was needed. $\mathrm{He}$ needed not only consultants to give him occasional advice, he needed fellows of the Library of Congress who could give their 
full time and full energy to the enormous tasks facing them. Consequently in the summer of 1940 five scholars were appointed as Resident Fellows of the Library of Congress.

\section{Make-Up of Consultant Service}

The Consultant Service of the Library of Congress as now constituted consists of five Resident Fellows of the Library of Congress, five Fellows of the Library of Congress (not in residence), four Consultants, a number of Honorary Consultants (for the most part not in residence), eleven Associate Fellows, a clerical staff, and the Administrator. The Resident Fellows of the Library of Congress are scholars in midflight on leave of absence from their universities. The fields represented for this year are: technology and library science, chemistry, folklore and Americana, naval history and contemporary Europe, and French literature. The stipends of the Resident Fellows of the Library of Congress equal the stipends they receive in their universities and their full time is devoted to the study of the Library of Congress problems as seen by research men.

The Consultants are, with one exception, displaced European scholars who have been stationed in the library through the kindness and generosity of foundations.

The eleven Associate Fellows are members of the Library of Congress staff who, because of their advanced study, are appointed to assist the Resident Fellows of the Library of Congress. The Associate Fellows are granted one day a week from their regular duties to survey the collections.

The Fellows of the Library of Congress were last year's Resident Fellows of the Library. Their appointment is honorary and the Librarian hopes that in the course of years a corps of Fellows of the Library of Congress will be built up throughout the country who will continue to give him advice on their special subjects.

\section{Functions of the Fellows}

As experience has accumulated with the Consultant Service it has become increasingly clear what functions these men can perform. In his letter of appointment in the summer of $194 \mathrm{I} \mathrm{Mr}$. MacLeish defined these as follows:

To survey and evaluate the collections in the library in his particular field.

To recommend the acquisition of individual items in his field, and to recommend an acquisition policy for the Library of Congress taking into account the position which the Library of Congress should assume in relation to other libraries.

To make recommendations calculated to improve the accessibility and the service and to extend the knowledge of the materials in his particular field in the Library of Congress.

These three fundamental duties raise problems which have not yet been entirely solved. The first is how to survey collections as large as those of the Library of Congress. It is, of course, no task at all to report that we have " $X$ " number of shelves in the classification covering nineteenth century French authors, that there is an average of " $N$ " number of books on each shelf and consequently that we have some fourteen thousand books in this class. The problem that faces the research worker is to discover whether these are the fourteen thousand books we want or just fourteen thousand books. It is obvious, for example, that through the operation of the copyright law the Library of Congress has collected an enormous num- 
ber of textbooks of interest perhaps to the future student of inter-cultural relations but of little interest to the research specialist. The discovery that in a number of cases we have duplicate sets for exchange, unique in the country, is gratifying. Less gratifying is the discovery that though we may have the latest critical edition of an author's work we do not have supplementary volumes which appeared a few years after the critical edition was published.

\section{Checklists}

In order to make these discoveries, to decide what is needed, the Resident Fellows of the Library of Congress prepare annotated, evaluative checklists of the one or two thousand books which would constitute a definitive basic collection for a research library. Indications are given for each item as to whether it would be needed in a library which would use it for oblique reference or in a college library where the subject is taught but where no advanced research is contemplated or in a large reference library. The lists are then searched to discover whether the items are in the Library of Congress and references are made to other places where they may be located. The items not in the Library of Congress constitute a desiderata list. The lists are made accessible to the general public and it is hoped that the special knowledge of the Resident Fellows of the Library of Congress may be used by libraries for purposes of checking and evaluating their collections. The judgment displayed in these lists is not the judgment of an isolated individual scholar ; the lists are built up through consultation with the forty or fifty most distinguished members of the field in universities and elsewhere.

A second type of list now being prepared is the encyclopedic reference list, for example, the hundred to hundred and fifty books in English which will cover authoritatively all aspects of the U.S.S.R., contemporary politics, etc. These are being annotated by men who know their subject thoroughly and will serve, we hope, as a useful reference guide.

\section{Recommend Books for Purchase}

The second duty of the members of the Consultant Service is to recommend books for purchase. The national bibliographies in their subject fields as well as their technical journals are made available to them as soon as they arrive in the library. By means of reviews and their knowledge of the personalities in their field they are thus able to recommend for purchase noncopyright books. In addition to these sources of information there are of course the usual sources, dealers' catalogs and so on. This duty is being performed conscientiously both by the Fellows of the Library of Congress in Residence and those not in residence.

The duty of improving the accessibility of the books resolves itself into conferring with members of the divisions of the Process Department, suggesting changes in the schedules or in added entries. When, for example, the Fellow of the Library of Congress in Population, whose specialty is differential fertility, found himself referred from "fertility" to "fecundity" in the catalog, he indignantly reported that should he use that term in any population convention he would be hooted off the platform. Conferences on these problems usually begin after the Fellows of the $\mathrm{Li}$ brary of Congress have been in residence for six or seven months and have familiarized themselves with problems of the $\mathrm{Li}$ brary. 
In addition to these duties the Consultant Service takes care of a very large amount of reference work, an amount which is increasing rapidly as the emergency increases.

To what extent this sort of service might be useful in a college library college librarians know better than I. They know, too, that libraries not attached to universities are apt to cherish an amiable illusion in that they imagine that college and university faculties are constantly at the librarians to improve and balance the collections. This is, unfortunately, not true in very many cases. Where there are library committees, presidents are apt to appoint good and able scholars but not to appoint men of the very first brilliance. Other library committees resent meeting with the librarians unless there is money to be spent and still others just don't function. Experience in the Library of Congress has shown that the training received by the Resident Fellows of the Library of Congress is of enormous value to them and the question arises as to whether it would not be wise to station members of the several departments in the college in the library for a year, reduce their teaching loads to the point which would enable them to confer actively both with librarian and student. This is the more needed, it seems to me, because of the need to tame the books. Although advanced research men fondly hope that before they die they will have read everything that has been written on their subject, none has realized that hope. How much more desirable, then, in an undergraduate college where students do not even have the wish to read everything that has been written on their subject, would it be to have available for several hours a day a man who has gone farther in his reading than the undergraduate and can assist the undergraduate in the wise selection of his books.

\section{Benefits from This System}

At least three benefits might be found to result from this system:

I. To the library. The librarian would have a specialist available at some regular time during the day who could advise him on purchase policy, cataloging problems in his field, arrangement and accessibility of his part of the collection, and other problems of importance.

2. To the faculty member. By becoming acquainted with the problems characteristic of a research library as a member of the staff he will be able to make better use of the collections than he has made. In addition, he will be given a certain amount of leisure which, it will be understood, he is to devote to the reading of his technical literature. Finally, by dealing with all of the students in his department he will get a better understanding of their needs and difficulties than is possible when he is principally in the classroom or in conference.

3. To the student. He will have the advantage of specialized advice from a faculty member who knows not only the special field of study on which the student is engaged but also the collections of the library and the problems faced by librarianship. 